\title{
LION AS SLAIN LAMB: ON READING REVELATION RECURSIVELY
}

\author{
Patricia M. McDonald, S.H.C.J. \\ Mount Saint Mary's College
}

\begin{abstract}
Because of their communities' experiences and tendencies, New Testament writers such as Paul and Mark stress the death and resurrection of Jesus as the source and model of the Christian life. In the Book of Revelation, John's version of this is that the lion of the tribe of Judah indeed "conquers" but does so as the Lamb who was slain; the Christian witnessing that leads to the victory of Christ's followers may also entail their death. Yet the seer associates the Lamb imagery with that of ancient near eastern and classical versions of the conquest myth. Does John risk subverting his own purposes? The paper examines his presentation of the Lamb and suggests that he does indeed run such a risk, at least for the inattentive reader, but this does not justify neglect of such a creative and imaginative soteriology in which evil is overcome by the word of God.
\end{abstract}

To Christians with an objection to violence, the Book of Revelation is often problematic, if not downright offensive. Although much of the work is not, in fact, violent at all, certain aspects of John's understanding of reality do seem to run counter to other normative expressions of Christianity. This paper seeks to investigate the extent to which John's use of the Lamb image is consistent with other New Testament writers' presentations of Jesus and to suggest why the seer's view of Christ and the Christian life is rather easily misconstrued.

Since twentieth-century readers have such a hard time interpreting it well, why bother with Revelation at all? On the one hand, energetic purveyors of a certain type of Christianity presume that this book contains all that one needs to know and is always directly applicable to the current situation. Taking no account of the conventions of its genre or of its canonical context, they inflict on those within reach embarrassingly naïve, ever-changing interpretations that reflect their own view of the prevailing political scene. On the other hand, most Catholics, while often entertaining fragments of the other view at the edges of their consciousness, are only too aware that Revelation was not

Patricia M. McDonald, S.H.C.J., is an Assistant Professor in the Theology Department of Mount Saint Mary's College (Emmitsburg, MD 21727). She holds degrees in biblical studies from the University of Cambridge, the Pontifical Biblical Institute, and The Catholic University of America.

HORIZONS, 23/1 (1996), 29-47 
written expressly for them and rarely go near it because it makes no sense and is, moreover, very disturbing in parts. ${ }^{1}$

Yet those who take the trouble to learn the conventions of late first-century apocalyptic will find in Revelation an understanding of Christ and an expression of soteriology quite on a par with those of Paul and the writers of Ephesians and Hebrews. John ${ }^{2}$ is passionately concerned to help the churches of Asia Minor understand what God has done for them in Christ and how that should affect their view of the world in which they live. He has an acute sense of local situations (chaps. 1-3) and of the wider contexts in which those are situated, and he draws on considerable imaginative creativity to express the tradition in his own way.

\section{The Starting Point: Salvation through Passion}

My starting point is the presumption, derived from the New Testament itself, that, probably greatly to their surprise, those who had followed Jesus during his lifetime experienced his death and resurrection as empowering them in a way that they had to interpret as salvation-a salvation which, as Jews, they would have understood as having divine origin. The perceived cause of this salvation, Jesus' death and resurrection, went against all the traditional expectations of a messiah who would overthrow Israel's current oppressors by military/political means.

The Christian understanding of how God works runs counter to almost all of our human instincts, ${ }^{3}$ which is why New Testament writers are trying hard (against the odds) to hold on to the central insight of the crucified Christ. There is something profoundly paradoxical in the idea that salvation comes through the death of a convicted criminal; we do not think of human achievements as coming about in this kind of way. We achieve through action, not passion (at least, we think we do). Furthermore, that Jesus' passion and its aftermath should be the revelation of what God is like is simply disorienting. What, then, does it mean to be "all-powerful," since it clearly does not mean forcibly overpowering one's enemies? Could it be that the meek, the gentle,

${ }^{1}$ Catholics have not always neglected the Book of Revelation. See, e.g., Richard K. Emmerson and Bernard McGinn, eds., The Apocalypse in the Middle Ages (Ithaca and London: Cornell University Press, 1992).

${ }^{2}$ With most contemporary scholars, I take it for granted that the seer of Revelation is what he says he is: someone called John, a servant of Jesus Christ (Rev 1:1) who is the recipient of prophecy $(1: 3 ; 10: 11 ; 22: 18-19)$ and sees himself as having particular pastoral responsibility for at least some of the churches in Asia Minor (Rev 2 and 3). He is familiar with a variety of traditions, both ancient (e.g., the Old Testament) and more contemporary (e.g., Jesus material that is witnessed to other New Testament components, including the Synoptic, Johannine, and Pauline strands).

${ }^{3}$ On this, see Walter Wink, Naming the Powers: The Language of Power in the New Testament. vol. 1, The Powers (Philadelphia: Fortress, 1984), esp. 113-15. 
really will inherit the earth? Is human freedom (other people's freedom, that is) so important that God is revealed in Christ's submission of its exercise, not in the vanquishing of those who do not share God's viewpoint?

Such an attitude can occasionally make sense: people do sometimes find themselves enabling others by letting them be rather than subduing them by force or manipulation. It is, however, quite something else to translate this into sustainable daily practice and to figure out its social consequences for any given situation.

\section{Paul, Mark, and John the Seer on the Primacy of the Passion}

Even in some of the earliest New Testament writing we see Paul struggling with this problem, as he tries to keep the Corinthians on the right track. In the first chapter of 1 Corinthians he insists: "[W]e proclaim Christ crucified... to those who are called, Jews and Greeks alike, the power of God and the wisdom of God. For the foolishness of God is wiser than human wisdom, and the weakness of God is stronger than human strength" (vv. 23-25, in part). The Christians in Corinth want to be wise and strong, but they are going about it in quite the wrong way.

Similarly, Mark, a few decades after Paul, takes it for granted that people wish for "life," to be "the greatest," "the first," to sit with Jesus in his glory (chaps. 8, 9, and 10); but, as becomes evident from the teaching on discipleship that follows each passion prediction, these goals are achieved not by clinging to life, pushing oneself forward, or clamoring for the ear of the powerful, but by diligent and humble service. This, after all, is the way of Jesus.

My thesis here is that John, in his much more ambitious book, is trying hard to present the same picture of Jesus and of the Christian life. His choice of the slain Lamb (arnion) image is a significant part of that attempt. Yet, although this ought to be a fine way of counteracting the tendencies to see God's achievement in Christ as an imposition of power, some of the contexts in which John speaks of the Lamb seem to risk the subversion of such a purpose. Whether or not he realizes it, the seer repeatedly exposes the reader to triumphalist ways of thinking and speaking. I wish to investigate how they got to be that way and what those who believe in God and in the slain Lamb can do about it.

By way of a preliminary, I take it for granted (against Luther and other worthies, ancient and modern) that the crucified Christ is central to the Book of Revelation. The following texts support such a position. The "one like a son of man" (1:13) introduces himself as "the first and the last, the one who lives. Once I was dead, but now I am alive forever and ever" (1:18). The Lamb is presented in 5:6 as "a Lamb that seemed 
to have been slain," hymned as such in 5:12, and reintroduced in 13:8 as "the Lamb who was slain." The Lamb's blood is mentioned in 7:14 and 12:11. Thus, the readers, presumably identifying with those who belong to and/or follow the Lamb (the same two verses, plus 7:9; $14: 1,4 ; 19: 9 ; 21: 14$ ), should not be understanding themselves as part of a marauding messiah's entourage. Contributing to this basic paradox are the further ones, that the Lamb's blood makes robes "white" $(7: 14)$ and the Lamb "will shepherd them" (7:17). Like other new Testament authors, John is trying to present, in all its strangeness, the central Christian understanding of how and why things are as they are.

\section{The Lamb in Revelation 5}

Although there is significant christology in Revelation 1:3, I nevertheless wish to start with a consideration of chapter 5 . Here, following his presentation of creation in chapter 4, we find John's version of the redemptive process, a process that puts in place all the other circumstances and events described in the remaining chapters of John's work. The story can only continue (and the communities addressed in chapters 2 and 3 can only exist) because the "Lamb that seemed to have been slain" (v. 6) is uniquely deemed worthy to take the scroll from the enthroned one and open its seals (5:3-5). Thus the Lamb's action (which its prior passion enables it to perform) sets in motion the narrative that moves from the old creation (chap. 4) to the new creation in chapter 21. In the latter chapter the image of the Lamb reappears as the bridegroom of the holy city, Jerusalem, itself the only element of the "new heaven and ... new earth" (21:1) that is of interest to the seer. Thus we need to look carefully at chapter 5 and, in particular, the figure of the Lamb that it presents.

Even though scholars cannot agree on its conceptual parentage, ${ }^{4}$ the Lamb is, as John sees it, one "that seemed to have been slain" $(5: 6)$. Its significance is gradually elucidated in verses $9-14$ by means of the three hymns that John hears. First, the four living creatures (representing creation in all its mystery) ${ }^{5}$ and the twenty-four elders (who can be

${ }^{4} \mathrm{G}$. B. Caird, in The Revelation of St. John the Divine, Harper's New Testament Commentaries (New York and Evanston: Harper \& Row, 1966), 74, insists that, since John himself "has told us what he means by it," searching Jewish literature is unnecessary. Loren L. Johns, in a presentation at the 1994 Annual Meeting of the Society for Biblical Literature, ignored Caird's advice. His exploration of six biblical and various extrabiblical possibilities (the Testaments of Joseph and of Benjamin; 1 Enoch) led him to conclude, however, that, as no one source is sufficient to account for John's portrayal of the Lamb, the seer himself may well have invented the imagery.

${ }^{5}$ See U. Vanni, "Il simbolismo nell'A pocalisse," Gregorianum 61 (1980): 461-506, at 470-71. Vanni notes that theriomorphic (animal) symbolism in general is oscuramente superiore rispetto al livello degli uomini (471 and n. 23): it refers to a level of reality somehow transcending that at which humans operate. 
thought of as Israel plus the church) ${ }^{6}$ hymn the lamb with "a new hymn" (ódēn kainēn, new in quality, not just in time, v. 9). Clearly the story has progressed since chapter 4 . In song, they praise the Lamb as "slain" (5:9, repeated in v. 12), and John hears that its blood is the ransom for people of "every tribe and tongue, people and nation" (ibid.). The honor due to the Lamb for this is further specified by the same group plus "countless" angels (v. 11), and in the third hymn John hears the doxological response of "every creature in heaven and on earth and under the earth and in the sea, everything in the universe" as they cry out: "To the one who sits on the throne and to the Lamb be blessing and honor, glory and might, forever and ever" (5:13). This response is ratified (v. 14) by the "Amen" of the four living creatures and the worship of the elders, that is, by the official representatives of creation. The first cycle in which John presents his understanding of how things are then ensues, as the Lamb opens each of the seven seals.

What is this Lamb, though? With its seven horns and seven eyes, it is clearly on the side of God. There is, however, more of it than meets the eye. For its original introduction, given through John's hearing, not his sight, specifies it as "the lion of the tribe of Judah" (v. 5). There is, on the whole, a distinction between what John sees and what he hears. As Sweet and others have noticed, hearing tends to give the inner reality of what is seen (note, in particular, Rev 13:11). ${ }^{7}$ In the case of the Lamb in chapter 5, admittedly, the distinction between seeing and hearing is not absolute; although the significance of what John sees is given by his auditory experiences (the three hymns and the creatures' "Amen"), the worship of the elders is (presumably) something that he sees. Nevertheless, since one of the elders first drew John's attention to the Lamb by terming him "the lion of the tribe of Judah, the root of David," this designation is surely important.

At one level, of course, it is simply a way of making sure the reader gets the reference to Jesus: Judah is an ancestor of David, whose descendant Jesus is. ${ }^{8}$ The "lion" image is part of this, for the dying Jacob uses it to describe Judah when blessing each of his sons (Gen 49). According to Genesis 49:9-11, "Judah, like a lion's whelp," is formidable as predator and ruler.

Yet, what John says about the lion of Judah does not depend on Genesis 49, for John's lion is able "to open the scroll with its seven

${ }^{6}$ Ibid., 491.

${ }^{7}$ Yet the understanding of that inner reality is, as a rule, determined by the concrete Christian experience; this is the basis of Caird's "rebirth of images" (Revelation, 73). See, e.g., John Sweet, Revelation, TPI New Testament Commentaries (Philadelphia: Trinity Press International, 1990), 125-32.

${ }^{8}$ Paul and the synoptic gospels testify to Jesus' Davidic ancestry (see, e.g., Rom 1:3-4; Mk 10:47-48, and Matthew's and Luke's infancy narratives and genealogies); Jn 7:42 probably implies it, in ironical fashion. 
seals" (Rev 5:5) because he "was victorious" or "conquered" (enikesan), a verb that is not part of Jacob's blessing of Judah. So what might be the source of this verb as it applies to Jesus (and, therefore, to Christians) in the Book of Revelation? The answer would seem to be twofold: the Johannine tradition and cosmic myth.

Aside from Revelation where it appears sixteen times, the verb "to conquer" (nikan) is much more frequent in the Johannine corpus than elsewhere in the New Testament: of the other eleven New Testament occurrences of the word, one is in the Fourth Gospel, and six are in 1 John. ${ }^{9}$ Within this tradition, Jesus has "conquered the world" (Jn 16:33) and so have Christians (1 Jn 5:4,5). Christians have, therefore, "conquered the evil one" and the false prophets who belong to "the world" ( 1 Jn $2: 13,14 ; 4: 4-5)$.

The usage of nikan in Revelation is, however, distinctive inasmuch as when the seer writes of the Lamb or Christians as "conquering," the verb is mostly used in an absolute sense, i.e., without an object, in phrases like "the one who conquers." The first nine uses and the last one are of this type. ${ }^{10}$ In the three exceptions (in 12:11, 15:2, and 17:14), nikan is used transitively, but its direct object is never "the world" or "the evil one" as in the Johannine tradition. Here, Christians are said to have conquered both "the beast" (15:2), while in 17:14 the angel tells John that the Lamb will conquer the beast and its allies. This is where the second element, the combat myth, comes in.

\section{The Combat Myth Background}

Adela Collins is surely right in claiming that John has been strongly influenced by the various combat myths that were widespread in the ancient near east and the classical world. As Collins points out, "nearly every major ethnic tradition had one or more versions of its own," including "Sumerian-Babylonian, Hittite, Canaanite-Ugaritic, Greek, and Egyptian" traditions. ${ }^{11}$ The more familiar of these include the Babylonian Enuma Elish, the Greco-Roman Leto-Python-Apollo myth, and the Egyptian one about Isis, Horus, Osiris, and Seth, but there are many more. There is much evidence that parts of the Old Testament (including proto-apocalyptic texts such as Zechariah 9) were

\footnotetext{
${ }^{9}$ The other New Testament occurrences of nikan are in Lk 11:22 (a parable about a "strong man" being overcome by one stronger); Rom 3:4 (quoting Ps 51:6, where it means "acknowledged as just"); and Rom 12:21 (where Paul exhorts his readers not to be conquered by evil but to conquer evil with good). The link with the Johannine usage is not strong, although the example of Jesus presumably underlies all of them. (See also Rom 8:37, where Paul makes the link between Christians' act of conquest-hypernikōmen-and their experience of divine love).

${ }^{10} \mathrm{This}$ is the case in Rev 2:7,11,17,26; 3:5,12,21(2x); 5:5; $21: 7$.

${ }^{11}$ Adela Collins, The Combat Myth in the Book of Revelation, Harvard Dissertations in Religion 9 (Missoula, MT: Scholars Press, 1976), 57, 209.
} 
influenced by such myths, especially in its Canaanite form of the battle between Baal and Yamm, the sea god. ${ }^{12}$

The myth goes like this. Two divine beings and their associates dispute about who is to possess universal kingship. On the one side is a monster (or, quite frequently, two of them, of which one is often a dragon); this represents the forces of chaos (and, therefore, infertility). Opposing the monster(s) is the divine champion of order and fertility; he is first defeated in battle and then reinstated. Obviously, the outcome of the combat has profound consequences for nature and human society.

Different scholars have found slightly different elements in the literary form of this myth but I have followed Collins's lead in taking P. D. Hanson's analysis of the Enuma Elish as a convenient typical example. Thus:
a. Threat (I.109- II.91)
b. Combat-Victory (IV:33-122) ${ }^{13}$
c. Theophany of the Divine Warrior (IV:39-60)
d. Salvation of the Gods (IV:123-46; VI:1-44; cf. VI:126-27, 149-51)
e. Fertility of the Restored Order (V:1-66; cf. VII:1-2, 59-83)
f. Procession and Victory Shout (V:67-89)
g. Temple Built for Marduk (V:117-56; VI:45-68)
h. Banquet (VI:69-94)
i. Manifestation of Marduk's Universal Reign (anticipated: IV:3-18; manifested: VI:95 - VII:144). ${ }^{14}$

\section{The Seer's Use of the Combat Myth}

Collins shows that the seer of Revelation knows about and has used various forms of this myth, both Jewish and Gentile; Asia Minor of the first century would have provided ample material. ${ }^{15}$ She finds that in the Book of Revelation the pattern of this story occurs in its fullest form in chapter 12 (in which, as noted above, Christians are said to have "conquered" the accuser); earlier chapters of Revelation contain elements of it that are brought to completion in the remainder of the book, culminating in the descriptions of victory and salvation in chapters $19-22 .{ }^{16}$ The first presentations are allusive, but, through rep-

${ }^{12} \mathrm{Ibid}$., 208, for P. D. Hanson's analysis of Zechariah 9.

${ }^{13}$ The Divine Warrior, Marduk, is not killed in this version of the myth.

${ }^{14}$ Collins, The Combat Myth, 209, taken from Paul D. Hanson, "Zechariah 9 and the Recapitulation of an Ancient Ritual Pattern," Journal of Biblical Literature 92 (1973): 37-59, at 54 .

${ }^{15}$ Collins, The Combat Myth, Appendix, 245-61.

${ }^{16} \mathrm{Ibid}$., chaps. 3 and 5. 
etition, there is a gradual clarification so that readers eventually come to see the world in the way that the seer intends that they should. ${ }^{17}$

It seems fair to say that, as used in the Book of Revelation, the combat myth is something of a two-edged sword. Positively, its use enables John to convey in a vivid manner the radically all-pervasive effects of Christ's death: cosmic claims are involved here. One needs to ask, though, whether the myth, by its very vividness, subverts the seer's fundamental intention of presenting a crucified Christ, inasmuch as it tends to pull the reader in a direction contrary to the "Jesus pattern" that I referred to above, in which achievement results not from conquest but from passion.

For a start, the myth reinforces John's view of life as adversarial. $\mathrm{He}$ is acutely sensitive to the dangers posed by both the power and the allure of Rome. It is not surprising that he should be aware of Rome's power: he is, after all, on Patmos because he "proclaimed God's word and gave testimony to Jesus" (1:9). Besides, he knows that Antipas of Pergamum was martyred (2:13) and that civil authorities may at any time take their cue from (the late, unlamented) Nero and kill off Christians who make nuisances of themselves. The messages to the churches imply communities that are essentially powerless (see, e.g., $2: 9,13 ; 3: 8$, referring to Smyra, Pergamum, and Philadelphia). ${ }^{18}$ Later chapters reinforce that suggestion with more graphic indications of the control that the empire has over those who live in it; in chapter 13 and the "Babylon Appendix" of 17:1-19:10, John vividly shows the military, political, and economic power of the beast and the harlot, even as he describes its overthrow.

Whereas some of John's readers need strengthening to face the possibility of harassment and even death for their witness to Jesus, others are more at risk from the equally dangerous allure of conformity to the values of the empire ("accept[ing] the mark of the beast," 19:20; cf. 13:16-18). For John, being counter-cultural is of the essence, given the nature of the surrounding society: those communities that do not feel their powerlessness are in even more danger than those that do. So he is especially hard on the complacency of Sardis (3:1) and Laodicea (3:17). Again, in 17:1-19:10 (and especially 18:11-23) he indicates what imperial society can make available; those who refuse conformity have no chance at all of access to its luxuries (18:11-13) and can never really own even the more ordinary manifestations of civilized life (18:22-23). The seer makes no secret of the high cost of remaining faithful to Jesus.

\footnotetext{
${ }^{17}$ Ibid., 44, where Collins is dependent on Ricoeur, Lévi-Strauss, and Wayne Meeks.

${ }^{18}$ Ephesus and Thyatira $(2: 2,19)$ probably belong here, too.
} 
Since, then, John is trying to encourage his readers to continue their witness in these perilous circumstances, it makes sense that he should present Christ as the ultimate victor. So the combat myth and the traditional "lion of Judah" would, it seems, serve him well.

Yet he cannot use the lion image in its Old Testament form. Although his lion of Judah "conquers" (a verb missing from Gen 49), it does so not in a lion-like way, by tearing its prey to pieces and devouring it, nor even in the military way that the imagery surely implies, employed by King David so successfully in Israel's past, and expected by at least some Jews to be used by the Messiah. ${ }^{19}$ Indeed, there is in Revelation 5 no mention at all of prey, opponent, or enemy for, as noted, the "lion" about which the elder tells John turns out to be a slain lamb. ${ }^{20}$ Although elsewhere in Revelation lion imagery is used to terrify (9:8,17; 13:2), this is never done in connection with the lion of Judah.

In other words, John is like Paul, Mark, and other New Testament writers who insist that any existing expectations about the Messiah be subjected to the reality of Jesus and not vice versa. (So Hilary of Poitiers: "Non sermoni res, sed rei sermo, subjectus est.") ${ }^{21}$ Thus, what John says about the lion in Revelation 5 shows that Jesus' powerful victory that led to the salvation of the redeemed (see 5:9-10) resulted not from an act of physical prowess (leonine or conventionally messianic) but from his crucifixion. ${ }^{22}$ In Revelation, the lamb has triumphed not by action (and certainly not by violent action) but by enduring the hostile action of others - in other words, by passion, understood as an accomplishment of the highest sort. It is this, also designated "wit-

\footnotetext{
${ }^{19}$ See, e.g., Psalms of Solomon 17:21-25; in v. 25 the sight of this descendant of David suffices to make the nations flee. A convenient source is James $\mathrm{H}$. Charlesworth, ed., The Old Testament Pseudepigrapha, vol. 2 (Garden City, NY: Doubleday, 1985), 639-70. The first century C.E. manifests a variety of Jewish expectations about the messiah. See, e.g., Jacob Neusner, William S. Green, and Ernest Frerichs, eds., Judaisms and Their Messiahs at the Turn of the Christian Era (Cambridge: Cambridge University Press, 1987), and, more recently, John J. Collins, The Scepter and the Star: The Messiahs of the Dead Sea Scrolls and Other Ancient Literature, The Anchor Bible Library (New York: Doubleday, 1995).

${ }^{20}$ The Lamb could even have been offered as a sacrifice. As Sweet (Revelation, 128) notes, the sacrificial sense of sphazo, the verb translated as "slain," "was prominent in secular Greek and predominant in LXX." However, John's use of sphazō elsewhere in the book $(6: 4 ; 13: 3 ; 18: 24)$ gives no support to this interpretation.

21 "The reality is not subject to the word but the word to the reality" (Hilary of Poitiers, De trinitate 4, quoted to good effect by Karl Barth in Church Dogmatics I.1: Doctrine of the Word of God [Edinburgh: T. \& T. Clark, 1936], 407). See Stephen McKenna, ed., St. Hilary of Poitiers: The Trinity, The Fathers of the Church: A New Translation 25 (Washington, DC: Catholic University of America Press, 1968), 103.

${ }^{22}$ Christian tradition came to interpret Jesus' crucifixion in various ways, one of the more prominent of them being on the analogy of the ritual sacrifice of a lamb without blemish. On this, see, e.g., Ex 12:5; Ezek 46:13; Heb 9:14; 1 Cor 5:7; 1 Pet 1:19; and probably Jn 1:29,36. Isa 53:7 is also relevant to the whole picture of "lamb" christology. See Sweet, Revelation, 124-25.
} 
nessing" or "testimony"23 (Greek: martyria and its cognates), that John's readers are to emulate.

In the remainder of the essay I shall be trying to show that this is John's best understanding of Jesus but that the use of "conquering" imagery, especially in conjunction with the combat myth, is risky because it can very easily convey an attitude that is representative of preChristian, unconverted notions of what Jesus (as Messiah) was about. In fact, John's task here is exceedingly difficult. For the seer is undertaking (among other things) to convince his readers that, despite appearances, divine justice is still operative in the larger scheme of things. So he commits himself to writing about the fate of the whole of creation, including malignant spirits and those people and institutions that buy into their ways of being. His treatment of these negative elements will include imagery that many have interpreted in a manner incompatible with John's basic Christian insights, as we shall see.

\section{The Triumph of Passion}

Because of all that it represents, the victorious lion/lamb figure in chapter 5 is the paradigm for interpreting other parts of Revelation. Thus, the prior reference in Revelation 3:21 to the son of man's act of conquering (ho nikōn) and its repercussions must be understood in light of it. ${ }^{24}$ In 3:21 Jesus says, "I will give the victor [lit.: the one who conquers] the right to sit with me on my throne, as I myself first won the victory [conquered] and sit with my Father on his throne." Christians, like Christ, conquer, but only in the way that he did. Therefore, each of the seven references to "the one who conquers" in the messages to the seven churches of Asia Minor in chapters 2 and $3^{25}$ is about the patient endurance [hypomone] John shares with them in Jesus (1:9), not about forcing one's will on others. As Wilfrid Harrington notes, "[T] he reality was that 'conquering' meant dying!" 26

The same is true in other parts of Revelation. The main examples are in 12:11 and 21:7. In Revelation 12:11 John writes that Christians conquered their "accuser" (Satan) "by the blood of the Lamb and by the word of their testimony": as in the case of Christ, this involves their death. Revelation 21:7 specifies that "the victor will inherit these gifts" and will be in filial relationship to God. In all these instances where Christians are the subject of the verb nikan, "conquering" (or

\footnotetext{
${ }^{23}$ In Rev 1:2, e.g., John "gives witness to the word of God and to the testimony of Jesus" (both genitives are subjective).

${ }^{24}$ John presumably expects his audience to understand this on a first hearing because of current usage in Johannine communities.

${ }^{25}$ See Rev 2:7,11,17,26; 3:5,12,21.

${ }^{26}$ Wilfrid J. Harrington, O.P., Revelation, Sacra Pagina 16 (Collegeville, MN: Liturgical Press, 1993), 226.
} 
"being victorious") involves fidelity and endurance (and, sometimes, testimony) rather than hostile action, but because John characteristically approaches the world in terms of a beleagured "us" and a hostile "them," it is easy to forget this essential transformation of language when reading Revelation and, indeed, he sometimes forgets it himself. $^{27}$

Part of the problem is that in Revelation, "conquering" does sometimes involve the imposition of one will on another: this is certainly the case with 11:7 and 13:7, where the beast is "to wage war against ... and to conquer" first, the two witnesses and then the holy ones. Revelation 6:2, about the white horse, is similar: it is clear from the parallel with Luke 21:9-11 that what is involved here is war, ${ }^{28}$ the essence of which is overcoming enemies by the use of force. At the very least, in his use of "conquering" terminology, John is not exactly making it easy for his readers to grasp the transformation of images that he is, I believe, trying to effect here. They have to be very alert to remember that "conquering" means one thing when applied to the world in general and quite another in the sphere of the Lamb and his followers.

They must also be alert when reading Revelation 6:16. Here, after the Lamb has opened the sixth seal, people from every level of society seek desperately to hide from "the face of the one who sits on the throne and from the wrath of the Lamb." It seems that, by its association with a wrathful God, the lion of Judah has reverted to type. This is not, however, the case. Rather, the divine "anger" results from the seer's acceptance of the Jewish-Christian understanding that the kind of evil systemic in the Roman Empire cannot simply be overlooked by a God concerned about justice. In Revelation 6:16, those whose way of life causes them to be threatened by the divine activity are unwittingly attesting to its power and to the essential involvement of Christ (the Lamb) in it. Yet in the context of Revelation as a whole, the phrase "the wrath of the Lamb" is not especially helpful. Perhaps there is a risk of exaggerating the danger inherent in this phrase. Maybe no Christians could ever be certain enough of their closeness to God to presume to share in the divine wrath or to threaten others with it, but would one be wise to bet on it?

After the opening of the seals, the Lamb is not featured again until chapter 12. The coniext is interesting. The section begins: "Then war

${ }^{27}$ See below on Rev 19:21; 6:2 may be another example.

${ }^{28}$ See Caird, Revelation, 80. This remains true whatever one's precise understanding of the first horseman may be. The topic is much controverted because of the mixture of positive and negative imagery in $6: 2$ and consequent disagreement about how it relates to its context. For a recent treatment, see Allen Kerkeslager, "Apollo, Greco-Roman Prophecy, and the Rider on the White Horse in Rev 6:2," Journal of Biblical Literature 112 (1993): 116-21. 
broke out in heaven." Here, the image of a "war in heaven" waged by an archangel and the description of the war's consequences in 12:7-10 are so arresting that they risk eclipsing the interpretation that follows in vv. 10-12. For a box-office success one would surely back "Michael and His Angels vs. the Dragon and His Angels: Don't Miss the Throwing Down to Earth of the Huge Dragon, the Ancient Serpent, Who Is Called the Devil and Satan (etc.)" rather than "Lamb Gets Slain and Christians Give Their Testimony!" Yet John's panache is surely to be admired: the point of his book is that the slaying of the Lamb and subsequent Christian witness are sufficient to handle all the opposition that the cosmos can come up with. The implied message in Revelation 12 is that evil, however alluring and dramatic, is not ultimate. In this chapter the Lamb does not revert to lionhood. John is quite clear that, as before, the "victory" in heaven came about not because of what Michael did but because of the Lamb's passion on earth. ${ }^{29}$ So the seer can honestly present Christian witness as the way to deal with the "war" that the dragon is waging against Christians, the rest of the woman's offspring -always supposing that the readers are not still absorbed in images of Michael finally giving Satan his comeuppance. This supposition is not, however, to be taken for granted, given the priority and the arresting description of the "war in heaven" in 12:7-10.

The Lamb is next mentioned in chapter 14. If, in 14:1-5, the 144,000 "virgins" are indeed "the ritually pure soldiers around the militant Lamb-Lion," as J. M. Ford maintains, ${ }^{30}$ they certainly represent a potential slippage of the Lamb image from what I take to be the normative Christian position. That Ford can come up with such an interpretation is evidence of the thin ice on which John is skating, yet I do not find her view compelling. Even if, however, the imagery is military, as many commentators have held, ${ }^{31}$ it must be highly metaphorical. For although one cannot rule out a link with the Qumran expectation of the eschatological war, the context does not force (or even nudge) the reader in that direction. Admittedly, in Old Testament terms "virgins" would be technically ready for this war as for any other (see, e.g., Lev 15:18 and 1 Sam 21:5), ${ }^{32}$ but there is no reason for thinking that the "new hymn" that the 144,000 sing before the throne

${ }^{29}$ This goes counter to the expectation deducible from 11QMelchizedek and the War Scroll, where Michael's prevailing in heaven seems to be the cause of the Messiah's being able to prevail on earth. See, conveniently, Otto Betz and Rainer Riesner, Jesus, Qumran and the Vatican: Clarifications, trans. John Bowden (New York: Crossroad, 1994), 91-92.

${ }^{30} \mathrm{~J}$. M. Ford, Revelation, Anchor Bible 38 (Garden City, NY: Doubleday, 1975), 234.

${ }^{31}$ E.g., Caird, Revelation, 179; Sweet, Revelation, 222; Harrington, Revelation, 146; G. R. Beasley-Murray, Revelation, New Century Bible Commentary, rev. ed. (Grand Rapids, MI: Eerdmans, 1978), 223.

${ }^{32}$ See, e.g., Caird, Revelation, 179. 
has any military connection. Neither the "elders" who play harps in 5:8 nor the "victors" in 15:2 would suggest any such thing, and "harpists playing their harps" (14:2) are not exactly traditional components of military bands! So the "virginity" of the 144,000 is probably to be understood directly in terms of fidelity, ${ }^{33}$ rather than being rerouted through a military image. ${ }^{34}$

Much more problematic, at least at first glance, is the mention of the Lamb in 14:9-12, where it is assumed that the Lamb, along with "the holy angels," will regard it a privilege to observe the unrelenting torment of anyone "who worships the beast or its image, or accepts its mark on forehead or hand" (v. 9). The difficulty here, however, is not at all the Lamb's violence but the seer's claim in v. 12 that Christians will be sustained by the thought of such a prospect. In other words, John has got the Lamb very wrong here, but the problem is his own resentment of Christians' present situation in Roman society, not any feature of the Lamb as such.

The Lamb is mentioned in Revelation 15:3 where, on the analogy of Exodus 15, the redeemed sing "the song of Moses, the servant of God, and the song of the Lamb." Presumably this places the Lamb alongside the redeemed (see, e.g., Rev 1:12-20), despite the fact that his role in redemption is more central than that of Moses at the Exodus.

Then, finally, there is Revelation 17:14, part of the "Babylon appendix," where the ten kings united under the leadership of the beast "will fight with the Lamb, but the Lamb will conquer them, for his is Lord of lords and king of kings, and those with him are called, chosen, and faithful." Obviously, the war is not initiated by the Lamb but by the other side. Furthermore, the presumption is that the Lamb's "conquering" here will have the same quality as in the earlier examples, especially given the characterization of his followers. Yet the way John later takes up the imagery in chapter 19 makes one suspect that by this stage he is so thoroughly immersed in the world of the combat myth that he risks being submerged by it or, at least, drowning his reader. For, although the Lamb is not mentioned, the name of the white-

${ }^{33}$ The Old Testament does not explicitly associate Israel as virgin with the people's fidelity, but idolatry is graphically described in terms of a woman's sexual infidelity in, e.g., Ezek 16 and 23, and in Hos 1-3; in Hos 4, the first of the Lord's grievances against Israel is their lack of fidelity (v. 1).

${ }^{34}$ Not all commentators see military language here. Elisabeth Schüssler Fiorenza, e.g., in a careful consideration of 14:1-5, considers that "[t]he expression parthenoi [virgins] probably points ... to the cultic purity of the Lamb's followers as well as to their representation of the 'bride of the Lamb'" (see The Book of Revelation: Justice and Judgment [Philadelphia: Fortress, 1985], 181-203, at 189). Sweet (Revelation, $223 \mathrm{n}$. v) notes that the seer may intend a contrast with "the Galli, the emasculated priests of Cybele, the Great Mother, who was widely worshipped in Asia Minor." 
mounted warrior in 19:11-16 turns out to be "king of kings and Lord of lords" (v. 16), the same phrases (although in the reverse order) that were used of the Lamb in 17:14.

Granted, the "blood" in which this warrior's cloak has been "dipped" (19:13) is almost certainly his own, yet he "judges and wages war in righteousness" ( $v$. 11), is accompanied by "the armies of heaven" (v. 14), is described in very destructive terms (v. 15), and is billed as being about to provide an abundance of human and equine flesh for the carrion birds (vv. 17-18). It transpires that what kills the warriors and their mounts is "the sword that came out of the mouth" of this rider (v. 21), at which point "the birds gorge[d] themselves on their flesh." The slain Lamb has got himself involved in this?

It does, I think, make a huge difference that the sword ${ }^{35}$ comes out of the warrior's mouth, a depiction that suggests verbal sparring rather than physical. ${ }^{36}$ This description was first used in 1:16, at the introduction of "the one like a son of man" (v. 13). (He will threaten to use it to "wage war against" unfaithful Christians in Pergamum [2:16].) In chapter 19 the sword issues from the mouth of one who is called "Faithful and True" and "the Word of God" $(19: 11,13)$, the implication being that God's word will (somehow) make ineffective anything not in accordance with divine fidelity and truth. Thus, like the "lion of Judah," the activity of "waging war" in 19:11 may not be physically violent, but may rather require to be interpreted metaphorically rather than literally. ${ }^{37}$

In a work that has prophecy as its primary self-designation (see Rev $1: 3 ; 10: 11 ; 22: 7,10,18,19)$, such an interpretation is in line with the Old Testament tradition that sees God's word as able to "slay" in a way that is obviously not literal. Hosea 6:5 includes the statement:

I smote them through the prophets, I slew them by the words of my mouth. ${ }^{38}$

\footnotetext{
${ }^{35}$ The Greek word used here is rhomphaia. It is also used in 6:8, one of the four traditional Old Testament means by which the four horsemen (or, at least, some of them: the text is unclear) bring death; the Old Testament background is that of covenant curses, i.e., the expected consequences of breaking God's covenant that were threatened in such texts as Ezek 14:21. (The same instrument is denoted by a different Greek word, machaira, in Rev 6:4.)

${ }^{36}$ Wis 18:14-16 contains the idea of God's word as being like a powerful sword. See also Isa 49:2-3, where the servant of the Lord says that God made his mouth "like a sharp sword."

${ }^{37}$ This is not the case with the other two uses of machaira, sword, in 13:10,14: the first refers to a real possibility of Christians being killed and the second to the apparently mortal wound from which the Beast recovered, perhaps a reference to Nero's suicide, for which he used a sword; there were persistent rumors that he was not really dead.

${ }^{38}$ See also Isa 11:4.
} 
Yet when his readers see in Revelation 19:17-21 how John adapts Ezekiel's picture of the birds and beasts assembling to eat flesh and drink the blood of those who have come out against the Lord (Ezek 39:17-20), ${ }^{39}$ they could be forgiven for losing sight of the metaphorical aspect of the seer's image of the sword. Again, the vividness of John's language may seduce the reader into taking the images more literally than John intends.

This would, however, be a mistake; for in the wider tradition, the word of God not only slays but also heals. Psalm 107:20 says with reference to those who were sick: "He sent forth his word, to heal them and to snatch them from destruction." 40 John has told his readers that the one against whom the beast and its entourage "gathered to fight" is the equestrian Word of God and his "army"; the latter wear clean white linen (19:14), similar to that of the bride in 19:8, where it "represents the righteous deeds of the holy ones." This is, therefore, no ordinary battle lineup, however vividly the carrion birds' activity may later be described.

As one would expect from the seer's general understanding of the opposition elicited by Christ and his followers, the heavenly rider has only to appear (19:11-16) for his enemies to assemble against him, ready to fight (v. 19) ${ }^{41}$ (In fact, they have been ready for him since 16:14-16.) But no battle is described; what follows in v. 20 is the capture of the beast and the false prophet whose signs had "let astray those who had accepted the mark of the beast." These two are then "thrown alive into the fiery pool burning with sulfur" (v. 20), the ultimate fate of the damned. ${ }^{42}$ However it is achieved, ${ }^{43}$ there is certainly a profound fittingness in having one called "Faithful and True" (v. 11) and "the Word of God" (v. 13) cause the downfall of the pair whose raison d'être was to deceive others.

What, though, happens to those others? It may be that John himself implicitly leaves open the fate of those "killed by the sword" in 19:21, because it seems that at least the leaders of this group reappear in the new Jerusalem in 24:4. Let us now consider this in more detail.

${ }^{39}$ This scene and the related one in Rev 20:7-10 is prepared for in 16:14, where three sign-performing "demonic spirits" assemble "the kings of the whole world" at Armageddon for "the battle on the great day of God the almighty."

${ }^{40}$ Similarly, Wis 16:12 reads: "For indeed, neither herb nor application cured them, but your all-healing word, O Lord"; this is probably a reference to the Law.

${ }^{41}$ In Wis 2 a similar sentiment is graphically expressed in personal terms rather than as a military metaphor: the just one provokes the malice of others.

${ }^{42}$ See Rev 20:10, 14-15.

${ }^{43} \mathrm{John}$ may wish to imply that there was a battle that he chooses not to describe, or he may envisage a situation like that described in Psalms of Solomon 17:24-25, where the Davidic messiah has only to warn the "unlawful nations" to cause them to "flee from his presence." 


\section{The Ambiguous Doom of the Adversaries}

In Revelation 19:19 those "killed by the sword" are designated "the kings of the earth and their armies." The phrase "the kings of the earth" is one of the many ways in which the seer refers to those who oppose God. ${ }^{44}$ Even among that group of expressions, it has a particularly negative connotation. This is because, as Susan Mathews suggests, ${ }^{45}$ it usually designates a sub-group of "the inhabitants of the earth"; these are, by definition, "all whose names were not written from the foundation of the world in the book of life" (13:8) and, therefore, destined for "the pool of fire" (20:15). Since those battling "the Word of God" are "the kings of the earth and their armies" (19:19) and they are all "killed by the sword" (v. 21), if they are inevitably consigned to the pool of fire $(20: 15)$ that would be the end of them. This appears not to be the case, however. For when he writes of "a new heaven and a new earth" in chapter 21, John says of the new Jerusalem that "to it the kings of the earth will bring their treasure"46 (v. 24) and that "the treasure and wealth of the nations" will also end up there (v. 26). John is logically inconsistent here. The kings of the earth are both dead (indeed, consumed by carrion birds!) and yet contribute appropriately to the new city. If one assumes that this is not simply an oversight, what might its significance be? The seer's position probably results from both his message and the vehicle he has chosen to use for presenting it.

At the level of the message, he is convinced of two incompatible things: that which opposes God cannot ultimately survive, and no truly human achievement can be lost in the final restoration. In consequence, much of what is lamented with such poignancy in 18:9-23the city of Babylon itself, the long list of valuable items in which she traded, and the lives and talents of the people in her-is, perhaps, not

44 "The kings of the earth" are referred to as such in 1:5 (on this, see below, in text); $6: 15 ; 17: 2,18 ; 18: 3,9 ; 19:[18], 19 ; 21: 24$; see also $16: 14$ and $17: 20,12$ [2x]. Other ways in which John refers to his opponents are "the inhabitants of the earth" $(3: 10 ; 6: 10 ; 8: 13$; $11: 10[2 x] ; 13: 8,[12], 14[2 x] ; 17:[2], 8)$; "the nations" $(2: 26 ; 5: 9 ; 7: 9 ; 10: 11 ; 11: 2,9,18 ; 12: 5$; $13: 7 ; 14: 6,8 ; 15: 3,4 ; 16: 19 ; 17: 15 ; 18: 3,23 ; 19: 15 ; 20: 3,8$; see also $21: 24,26 ; 22: 2$ ); "the rest of the human race" (9:20); "those who claim to be Jews and are not" $(2: 9 ; 3: 9)$; "those who call themselves apostles but are not" $(2: 2)$; the Nicolaitans $(2: 6,15)$; the Balaamites $(2: 14)$ and the Jezebelites $(2: 20)$.

${ }^{45}$ Susan Mathews, "The Tribulation, the Kingdom, and the Patient Endurance in Jesus" (unpublished paper).

${ }^{46}$ Or their "glory"; the Greek word is doxa, that which in Revelation as a whole, is God's possession $(15: 8$; cf. $18: 1$ and $21: 11,23)$ and something that creation rightly gives to God and to the Lamb. The noun is used seventeen times in the book and the verb twice: the eternal attribution of glory to God in the heavenly liturgy $(4: 9,11 ; 5: 12-13$; $7: 12 ; 15: 4$ [verb]) is that which humans on earth should also be making $(11: 13 ; 14: 7)$. They are free to refuse (16:9) and Babylon even attempts to glorify itself (18:7, verb), but the eventual overthrow of such elements becomes an additional occasion for glorifying $\operatorname{God}(19: 1,7)$. 
lost but, after the passing away of "the former heaven and the former earth" (21:1), can find its place in the new Jerusalem. When this happens, the figure termed "Faithful and True" and "the Word of God" will have made good on his other name, the one "written on his cloak and on his thigh, 'King of kings and Lord of lords'" (19:16). Furthermore, then the title given to Jesus Christ back in 1:5, "ruler of the kings of the earth," will be true in actuality and not just in principle. Such an outcome requires, however, the transformation of "the kings of the earth" who lose the "war" that the rider on the white horse wages against them, in which they are "killed by the sword that came out of [his] mouth" (19:11,19,21).

John's chosen medium of apocalyptic permits such logical inconsistency, just as twentieth-century Roadrunner cartoons or Monty Python's Flying Circus do. It does not make sense to ask how, for example, the Roadrunner survives repeated reduction to two dimensions by motor vehicles or high-speed impact against vertical cliffs. Similarly, there is a sense in which the kings of the earth must "be killed" inasmuch as they represent intransigent evil. Yet John presents their plight as the result of deception by the "false prophet." So by having them killed by the sword of the mouth of "Faithful and True," the allpowerful "Word of God," and then not specifying that they are among those found eligible for the fiery pool, the seer can leave open the way for expressing his conviction that all that is noblest in human accomplishments can (in some way) become a component of the new Jerusalem in the "new earth."

It seems, then, that in John's understanding, the equestrian rider's "waging war in righteousness" and "killing" are not simply destructive in the usual manner of wars and killings; rather, because he is "Faithful and True" and "the Word of God," there is a strong possibility that Jesus is able to use the sword in his mouth to rectify the warping that had taken place and thereby make good that which had been corrupted by deception. This interpretation is not justifiable on the basis of chapter 19 alone, which presents the sword as merely a weapon of death that slays those who were deceived and turns them into carrion for the birds; it is, however, possible and even necessary if one takes into account John's wider viewpoint.

\section{Conclusion}

So what is the reader to make of John's slain Lamb christology? Overall, it is an impressively creative attempt to depict Jesus' power and its mysterious source, his death and resurrection. In chapter 5 especially (but in many other places, too), John does train the reader to understand that "conquering" means suffering and death, and not mil- 
itary prowess. Besides, he might reasonably have expected that, as Christians, such would have been their predominant outlook. His narrative tension would have been considerably reduced if he had had to insert explicit reminders at the climax of his account.

One may, however, feel quite entitled to ask whether, in developing the Lamb as he does, John is expecting too much of his readers and risks being misunderstood. The watchword for the reader of Revelation must be caveat lector. For the seer's use of battle imagery, in particular, undoubtedly reinforces people's tendencies to have an adversarial view of the world. Such a view is always to some extent inappropriate for those who accept God as creator and Jesus as incarnate Lord. That is not to say that we lack contemporary equivalents of the Roman Empire whose danger John recognized as his readers' adversary and seducer. Some strong candidates would surely include those individuals and countries that maintain their own prosperity through the buildup of armaments by exerting political pressure at home and by aggressive marketing abroad; those that promote the increasingly institutionalized widening of the gap between rich and poor nations, groups, and individuals; and short-sighted environmental policies that risk our planet's viability. It is tempting (but unhelpful) to demonize, and parts of Revelation encourage rather than caution against this, yet John's real message is that it is God's word that overcomes evil, even in the socio-political sphere.

Furthermore, by describing "the Word of God" as a warrior, John reinterprets but does not dispose of the view of the messiah as military, a view that, in its crass form, prevailed prior to Christianity and has been inclined to take over ever since. And even though a careful reading of 19:19-21 shows that the warrior's "army" (v. 19) does not fight, John is not explicit about this, so that those who, on quite other grounds, expect human participation in the eschatological battle are not firmly disabused of their error.

John himself manages to describe the Lamb's ultimate triumph in terms that restrict the "violence" to the only "weapon" available to his communities: the power of the Word of God. ${ }^{47}$ Read in this light by those who continually struggle to be followers of the slain Lamb and who, like John, care passionately about power and justice, ${ }^{48}$ Revelation conveys a vivid interpretation of what God has achieved in Christ and its consequences for human living. John's book is an essential part of the Christian tradition, even though the history of its interpretation

${ }^{47} \mathrm{He}$ also presupposes the existence of whatever force may be necessary to get the various beasts into the pool of sulfur, but that is not subject to human control and John has nothing to say about it (Rev 19:20 and 20:14-15).

${ }^{48}$ See Elisabeth Schüssler Fiorenza, Revelation: Vision of a Just World, Proclamation Commentaries (Minneapolis, MN: Fortress, 1991), 117. 
indicates all too clearly the dangers of giving any encouragement to those inclined to think that violence solves problems and, worse, that divine violence will solve all problems. ${ }^{49}$

${ }^{49}$ I should like to thank Bill Collinge, Dennis Hamm, S.J., Susan Mathews, Bill Portier, and Gerard Sloyan for their responses to earlier drafts of this paper. 